\title{
Dijital Propaganda ve Politik Başarı: 24 Haziran 2018 Cumhurbaşkanlığı Seçiminin Twitter Analizi*
}

\author{
Nurettin Güz (Prof. Dr.) \\ Ankara Hacı Bayram Veli Üniversitesi İletişim Fakültesi \\ nuretinguz@gmail.com \\ Orcid: 0000-0002-2038-5652 \\ Ceren Yegen (Doç. Dr.) \\ Mersin Üniversitesi İletişim Fakültesi \\ cerenyegen@mersin.edu.tr \\ Orcid: 0000-0001-9582-0711 \\ B. Oğuz Aydın (Doç. Dr.) \\ Gaziantep Üniversitesi Illetişim Fakültesi \\ boguzaydin@gmail.com \\ Orcid: 0000-0003-2061-1688
}

Başvuru Tarihi: 05.02.2019
Yayına Kabul Tarihi: 13.03.2019
Yayınlanma Tarihi: 22.07.2019

DOI: 10.17680/erciyesiletisim.522546

Güz, N., Yegen, C. ve Aydın, B. O. (2019). Dijital Propaganda ve Politik Başarı: 24 Haziran 2018

Cumhurbaşkanlı̆̆ Seçiminin Twitter Analizi. Erciyes İletişim Dergisi, 6 (2), 1461-1482.

DOI: $10.17680 /$ erciyesiletisim. 522546

\section{Öz}

İnsan zihninde olumlu bir konotasyona gebe olmayan propaganda, fikir ve tutumlara etki etme ve onları arzu edilen yönde biçimlendirme faaliyetidir. Dünyanın birçok yerinde benzer bir çok biçimde yürütülen propaganda faaliyetleri söz konusudur. Siyasetin beslendiği damarlardan olan propaganda, politik propaganda görünümleri bazında da bir hayli yaygındır. İletişim teknolojilerinden yararlanarak diyalojik olarak yürütülen dijital propaganda da, siyaset yapanların kamuya interaktif biçimde ulaşmasını sağladığından, bugün oldukça popülerdir ve siyasi partiler gibi, siyasi aktörler tarafından da tercih edilmektedir. Propagandanın bugün yoğun olarak meydanlardan, sosyal medyaya kayması ilgili durumun bir göstergesidir. Öyle ki Türkiye'de 24 Haziran 2018'de gerçekleştirilen Cumhurbaşkanlığı ve Milletvekili seçimleri adına sosyal ağlarda öne çıkan platformlardan olan Twitter’da birçok dijital propaganda yürütülmüş, sosyal ağlardaki kamuoyu güncel haberlere hedef kitle olmuştur. Çünkü dijital çağda kamuoyu sokakta olduğu kadar, sosyal ağlardadır ve gündemi bir ölçüde belirleme gücüne sahiptir. Bu yüzden bu çalışmada, Türkiye'de 24 Haziran 2018'de gerçekleştirilen Cumhurbaşkanlığı ve Milletvekili seçimleri öncesinde, Yüksek Seçim Kurulu'nun (YSK) Cumhurbaşkanı adaylarını resmen açıkladı̆̆ı tarihten (9 Mayıs 2018) itibaren 25 Haziran 2018'e kadar olan süreçte, ilgili adayların ve siyasi partilerin resmi Twitter hesaplarındaki paylaşımları, sosyal ağ analizi yöntemleriyle incelenmiştir. Çalışma neticesinde, siyasi parti ve adayların propaganda amaçlı sosyal ağ kullanımlarına ait bazı yapısal özellikler ve bu özellikler ile seçim bitiminde elde ettikleri politik başarı arasındaki ilişkiler ortaya koyulmuştur.

Anahtar Kelimeler: Propaganda, Dijital Propaganda, Twitter, Sosyal A $\breve{g}$ Analizi.

\footnotetext{
* Bu çalışma 18-19 Ekim 2018 tarihinde Mersin'dedüzenlenen “Uluslararası Dijital Çağda Illetișim Sempozyumu”nda "Bir Dijital Propaganda Mecrası Olarak Twitter: Cumhurbaşkanlığı Seçimleri Üzerine Bir Analiz” başlığıyla sunulan bildirinin genişletilmiş halidir.
} 


\title{
Digital Propaganda and Political Success: Twitter Analysis of June 24, 2018 Presidential Election
}

\author{
Nurettin Güz (Prof. Dr.) \\ Ankara Hacı Bayram Veli University Faculty of Communication \\ nuretinguz@gmail.com \\ Orcid: 0000-0002-2038-5652 \\ Ceren Yegen (Assoc. Prof. Dr.) \\ Mersin University Faculty of Communication \\ cerenyegen@mersin.edu.tr \\ Orcid: 0000-0001-9582-0711 \\ B. Oğuz Aydın (Assoc. Prof. Dr.) \\ Gaziantep University Faculty of Communication \\ boguzaydin@gmail.com \\ Orcid: 0000-0003-2061-1688
}

Date Received: 05.02.2019

Date Accepted: 13.03.2019

Date Published: 22.07.2019

DOI: 10.17680/erciyesiletisim.522546

\begin{abstract}
Propaganda that does not conceive a positive conotation in the human mind is an activity that influences ideas and attitudes and shapes them in the desired direction. There are many similar propaganda activities in many parts of the world. The propaganda which is the veins fed by politics is quite common in some aspects of political propaganda. Digital propaganda, which is conducted dialogically by using communication technologies, is also very popular today and is preferred by political actors as well as political parties because it enables the public to interact politically. Propaganda intensely involved in the social media as well as the streets, is indication of this situation. So much so that for presidential and parliamentary elections in Turkey on June 24, 2018 on Twitter that is one of the platform of the leading social network, many digital propaganda activities have been conducted and the public opinion on social networks, has been the current target audience to the news. Because, in the digital age, public opinion is in social networks as much as it is in the streets, and the public opinion has a power to agenda setting. So in this study, from the date that Supreme Election Board (YSK) announced the presidential candidates (May 9, 2018) before the presidential and parliamentary elections held on June 24, 2018 in Turkey, the sharings of the candidates' official Twitter accounts' will be examined until June 25, 2018 via social network analysis. As a result of the study, some structural features of political parties and candidates' use of social networking for propaganda purposes, and the relationship between these characteristics and the political success that they achieved at the end of the election were revealed.
\end{abstract}

Keywords: Propaganda, Digital Propaganda, Twitter, Social Network Analysis. 


\section{Giriş}

Kitlesel ikna ile inandırma faaliyetlerini niteleyen propaganda, günümüzde yeni medya tabanlı platformlarda da etkin şekilde yürütülmektedir. Önce geleneksel kitle iletişim araçlarından güç alan ve gelişen propaganda, son dönemde özellikle sosyal paylaşım platformlarında varlığını göstermektedir. Hemen her dönemde farklı amaç ve mecralarla gerçekleştirilen propaganda faaliyetleri özellikle seçim dönemlerinde artış göstermektedir (Güz, 2005). Dijital propaganda olarak tanımlayacağımız iletişim teknoloji ve olanakları tabanlı biçim ise, bugün dünyanın birçok yerinde yaygınlık kazanmıştır. Sosyal medyanın kamuoyu oluşturma ve gündem belirleme gücünü fark eden siyasetçiler, sosyal ağlar üzerinden propaganda faaliyetlerine yönelmiş durumdadır. Propaganda geçmişten bugüne, özellikle siyasal davranış noktasında bireysel ve politik yaşama yoğun şekilde nüfuz etmiştir.

Propagandanın birçok farklı alan gibi siyaset, toplumsal hayat, kültür, hatta sinema ve sanat ile ilişkisini anlamak için de birçok çalışma yapılmıştır. Bunlara bu çalışma ile de ilgili olan Walton'ın (1997) What is Propaganda, and What Exactly is Wrong With it? başlıklı çalışması, Clark'ın (2017) Sanat ve Propaganda adlı eseri, Akay'ın (2011) Güncel Türk Siyasal Yaşamında "Siyasal İletişim Danışmanı" Kavramı başlıklı doktora tezi, Camankulova'nın (2013) Kırgız Belgesel Sinemasında Propaganda adlı çalışması başta olmak üzere birçok örnek olarak verilebilir.

Dijital propaganda, içerisinde yaşadığımız enformasyon çağında ortaya çıkmış ve 21. yüzyılda dijitalleşmenin artmasına paralel olarak yaygınlaşmıştır. Alanın yeni olması ve içerisinde yaşadığımız asırda yaygınlaşması sebebiyle, dijital propaganda alanında yapılan bilimsel çalışmaların az olduğunu belirtmek gerekir. Bu yüzden bu çalışmada, 24 Haziran 2018'de Türkiye'de gerçekleştirilen Cumhurbaşkanı ve 27. Dönem Milletvekili seçimlerine farklı bir açıdan bakılarak, seçim öncesinde siyasi parti ve adayların Twitter üzerindeki dijital propagandaları incelenmektedir.

Çalışma, Yüksek Seçim Kurulu'nun (YSK) Cumhurbaşkanı adaylarını resmen açıkladığı 9 Mayıs 2018 ile seçimin gerçekleştirildiği 24 Haziran 2018 tarihleri arası dönemi kapsamaktadır. Belirlenen tarih aralığında, YSK'nın aday olarak açıkladığı altı Cumhurbaşkanı adayı ve sekiz siyasi partinin yapmış oldukları dijital propagandalar, Twitter platformu üzerindeki bağlantılarının oluşturduğu ağ yapısı üzerinden sosyal ağ analizi yöntemi ile incelenmiştir. Böylelikle dijital propaganda faaliyetlerini içeren ağa dair bazı özellikler ve bu özellikler ile politik başarıları arasındaki ilișkiler ortaya koyulmaya çalıșılmıștır.

Çalışma, 16 Nisan 2017 tarihinde kabul edilen Anayasa Değişikliği'nin ardından, "Cumhurbaşkanlığı Hükümet Sistemi"ne göre yapılan ilk Cumhurbaşkanlığg seçimlerine yönelik olması sebebiyle önemlidir. Günümüz toplumlarında iletișim, propaganda, alış-veriş, ticaret gibi birçok faaliyetin ağlar üzerinden geliştiği dikkate alındığında; kamu, siyasi aktörler ve diyalojik siyasal iletişim bağlamında sosyal ağ analizine odaklanan diğer çalışmalara yol gösterici bir nitelik taşıması, bu çalışmayı farklı kılmaktadır. Ayrıca, dijital siyasal propaganda bağlamında Twitter kullanımı ve politik başarı arasındaki ilişkiyi ortaya koymayı hedefleyen çalışmanın, yeni medya ve siyasal iletişim alanındaki araştırmalara katkı sağlayacak olması bu çalışmayı özgün kılmaktadır. Çalışmada önce propaganda kavramı üzerinde durulacak, iletişim teknolojileri, internet, sosyal medya konusuna değenildikten sonra, çalışmanın ana konusunu olușturan dijital propaganda ve Twitter ile ilgili bilgiler verilecektir. Daha 
sonra ise Türkiye'de yapılan Cumhurbaşkanlığı seçimlerinde kullanılan propaganda ile ilgili yapılan ağ analizleri üzerinden bir sonuca ulaşılmaya çalışılacaktır.

\section{Propaganda}

Propagandanın tarihinin insanlık tarihi kadar eski olduğuna ilişkin görüşler yaygındır (Rieger vd., 2013, 1). Propagandanın, en yalın haliyle etkili ve örgütlü inandırma/ ikna etme faaliyetlerini nitelediği belirtilmekte (Bernays, 2005), propaganda bireyler ve kuruluşların insanları belirli bir bakış açısı veya görüşe yönlendirmek amacıyla bilgi yayması (Saunders, 2013, 311) olarak adlandırılmaktadır. Üzerine "iknanın manipüle edilmesi" ya da "iknanın kötüye kullanımı" gibi tanımların da yapıldığı propaganda (Pratkanis ve Aronson, 2001) kişiler, kurumlar, farklı siyasal ve sosyal organizasyonlar tarafından kamuoyunu etkilemek, davranış ile düşünceleri yönlendirmek amacıyla kullanılmaktadır. Propaganda, taraflar arasında doğrudan çatışmanın gerçekleştiği süreçte "kararsız kitlenin kendi lehine çevrilmesi, yönlendirilmesi” süreci (Marrero, 2013) olarak dâhi tanımlanmaktadır.

Tarih içerisinde propagandanın kullanıldığı alanlar farklılık göstermektedir. Ülkeler arasındaki ilişkilerden iktidar mücadelelerine, sınıf çatışmalarından farklı siyasal ya da sosyal örgütlerin yönetimini ele geçirmek üzere insanları etkilemek amacıyla yapılan çalışmalara kadar birçok alanda propaganda hep etkili olarak kullanılmıștır. Ortaçağ Avrupası'nda ise dini kurumların propaganda yapmak üzere özel bir kurum oluşturması propaganda tarihi açısından önemlidir. Avrupa'yı saran din ve mezhepler adına mücadelenin yoğunlaştığı 30 Yıl Savaşları sırasında Kilise tarafından doğrudan propaganda amaçlı bir kuruluş oluşturulması dikkat çekicidir. Papa XV. Gregory'nin 22 Haziran 1622'de Protestan Reform Hareketinin etkileri ile mücadele etmek ve Katolik Kilisesinin görüşlerini sistemli ve devaml yaymak üzere kurduğu, daha sonra Sacra Congregatio de Propaganda Fide ismiyle bilinecek olan Congregatio Christiana Nomini Propaganda adlı kuruluş, dinî otorite tarafından oluşturulduğu için diğerlerinden farklıdır. Kiliseler arasındaki mücadelede kullanılan propaganda teknikleri farklı olsa da, doğrudan propaganda yapmak üzere olușturulması ve bunun adına da koymuş olması bu kurumu ayrıcalıklı kılmaktadır (Qualter, 1980, 255; Jowett ve 0’Donnell, 2011).

Tarih içerisinde üzerinde birçok çalışma yapılan ve hemen her sistemde gözlenen, bireylerin düşünceleri ile tutumlarına etki etmeyi amaçlayan propagandanın (Austin, 1941, 143; Ellul, 1973; Jackall, 1995) kurallarının ortaya konması ise daha çok 20. yüzyılda olmuştur. Propagandanın genel kuralları; a) Basitleştirme ve tek düşman, b) Tekrar etme, c) Sevilenleri kullanma (Domenach, 2003) olarak belirlenmektedir.

Beyaz, siyah ve gri başta olmak üzere propagandanın farklı türk ve teknikleri vardır. Beyaz propaganda kitleleri doğru bilgi ile, siyah propaganda yalan ve yanlışlarla, gri propaganda ise belirsiz argümanlarla etkilemeyi ifade eder. Gri propaganda psikolojik bir savaşı niteleyebilmektedir (Conserva, 2003; Tarhan, 2016; Cull vd., 2003). Bugün özellikle siyasi parti ve adaylar tarafından siyasi başarı için gerçekleştirilen politik propaganda çalışmalarına büyük harcamalar yapılmaktadır. Amaca ulaşmak için kamuoyu araştırmaları da bu bağlamda öne çıkmaktadır. Bununla birlikte, kamu ilişkileri ve propaganda için ödenen fonları harcamaya yönelik özgürlüğün oldukça sınırlı olduğunu öne süren yaklaşımlar da vardır (Güz, 2005; Yegen, 2018; Kosar, 2005). 
Propaganda kavramı tarih içerisinde önemini hep korumasına rağmen, Nazi Almanyası'nın propaganda tarihi içerisinde önemli bir yeri vardır. İkinci Dünya Savașı boyunca bütün taraflar ama özellikle Hitler'in Propaganda Bakanı Goebbels başta radyo ve sinema (propagandanın sanat ile iç içe olması sebebiyle) olmak üzere (Clark, 2017) farklı kitle iletişim araçlarını bu amaçla kullanmışlardır. Propaganda amacıyla oluşturulan içeriklerin bu araçlar yoluyla hedef kitlelere ulaştırılması propaganda için kitle iletişim araçlarının ne kadar etkili olduğunu göstermiştir. Geleneksel kitle iletişim araçlarını propaganda aracı olarak etkili bir şekilde kullanan Goebbels, radyonun propagandada öne çıkmasında büyük bir rol oynamıştır (Kuruoğlu, 2006). 20. yüzyılın ilk yarısında radyo ile başlayan ve daha sonra televizyonla devam eden kitle iletişim araçlarının toplumsal etkilerine ilişkin tartışmalar, daha sonra medya mülkiyetleri üzerinden "rıza üretimi" tartışmalarını gündeme getirmiştir (Uçkaç Altun, 2010, 24).

Nazi dönemi Alman propagandasının başta Alman halkının ulusal üstünlüğü ideası olmak üzere bir takım ilke ve argümanları vardı (Austin, 1941). Goebbels'in damgasını vurduğu ilkeler arasında; propagandacıların olaylara ve kamuoyuna ilişkin istihbarat erişimine sahip olması, propagandanın sadece bir otorite tarafindan planlanması ve yürütülmesi, bir eylemin propaganda sonuçlarının eylemin planlanmasında dikkate alınması, propagandanın düşmanın politikasına ve eylemini etkilemesi vardır. Yine, propagandaya ilişkin kampanyayı uygulamak için açıklanmış operasyonel bilginin mevcut olması, propagandanın izleyicinin ilgisini uyandırması ve etkili iletişim aracı aracılığı ile iletilmesi, güvenilirliğin propaganda çıktısının doğru veya yanlış olup olmadığını belirlemesi, düşman propagandası ile mevcut propagandanın konumunun düşman propagadasının dikkate alınıp alınmayacağını belirlemesi ilkeleri vardır. Devam ile güvenilirlik, istihbarat ve iletişimin olası etkilerinin propaganda içeriğinin sansürlenmesini gerektirip gerektirmediğini ortaya çıkarması, düşman propagandasından elde edilen materyalin düşmanın prestijini azaltma veya kendi hedefi için yararlanılması, güvenilirlik ve etkisi dikkate alınarak beyaz propaganda yerine kara propagandanın kullanılması, propagandanın; liderlerin prestijinin etkisi için kullanılması, zamanlamasının dikkatli yapılması, olayları ve insanları farklı ifadeler veya sloganlarla etkilemesi bu ilkeler arasında yer almaktadır. Sivil insanlar ve askerlere yönelik propagandanın; geleceğe yönelik yanlış umutları önlemesi, en uygun kaygı düzeyini yaratması, hayal kırıklıklarının etkisini azaltması bu ilkelerdendir. Yine propagandanın; nefret hedeflerini belirterek saldırganlığın yer değiştirmesini kolaylaştırması, güçlü karşı eğilimleri doğrudan etkilemeyeceği dikkate alınarak bunun yerine bir tür eylem veya saptırma ya da her ikisini birden sunması Goebbels'in propaganda ilkeleri içerisindedir (Doob, 1950, 422-440).

Propaganda çoğu zaman halkla ilişkiler ve reklamcılık olguları ile karıştırılmaktadır. Ayrıca, propagandanın bir "etkileme stratejisi" mi yoksa bir "iletişim durumu" mu olduğu da tartışılmaktadır. Kuşkusuz propagandanın reklam ve halkla ilişkiler ile yakın bir ilişkisi vardır, fakat propaganda ilgili olgular ile aynı anlamda değildir, onların kullandığı bir argümandır. Bununla birlikte, propagandanın halkla ilişkiler ve reklamcılık ile ilişkisinin, tarihsel süreç ve bağlamlar temelinde tartışılması ve doğru analiz edilmesine (Karaçor, 2006, 86) ihtiyaç vardır.

\section{2. İletişim Teknolojileri, İnternet ve Sosyal Medya}

İletişim ve bilgi teknolojileri, teknolojik yenilik ve gelişmeler bağlamında hemen her gün bir çok alanda yenilikler sunmaktadır. İnternet ise bu duruma paralel, 
bugün dünyanın birçok yerinde yaşayan insanların en önemli bilgi kaynaklarının başında gelmektedir. İnternete ulaşma ve kullanma oranları küresel boyutlu olarak büyük ölçüdedir. İnternet birçok alan gibi propaganda, dezenformasyon ve misenformasyon için de önemli bir mecradır. Dünyanın hemen her yerinde yoğun ve yaygın olarak kullanılan internet, karar almayı doğrudan etkilemektedir. Doğrular ile yanlışların kolay yer değiștirebildiği bir alan olan internet, bireyleri yönlendirebildiği gibi (Bartlett ve Miller, 2011), hızı sebebiyle insanların bilgi alma şeklini dâhi değiștirebilmektedir (Neelamalar ve Chitra, 2009, 125). Dijital ortamın içerdiği alanlardan olan internet; iletişim, satış ve hizmetler için genel işin bir parçası haline gelmekte, uygulamaları değiştirmektedir. Hatta internet teknik sınırlamaları, malzeme miktarını ve malzemeye erişim hızını dâhi etkilemektedir (Njoroge, 2013, 8).

Devrimleri içeren modernizmin (Childs, 2008), bir anlamda dijital modernizmin (Kirby, 2009) bir sonucu olarak da yorumlanabilecek olan alan, dijital teknolojiler temelinde ilerlemekte ve bizleri yeni alan ve kavramlar ile tanıştırmaktadır. Örneğin dijital öğrenme, dijital yerliler, dijital göçmenler ${ }^{1}$, ağ pratikleri bunlardan bazılarıdır ve dijital sürece eklemlenen ve eklemlenme yolunda olan birey ve pratiklerini nitelemektedir. İnternet kullanımı, bugün dijital çağdaki çocukların hayatlarının ayrılmaz bir parçası olmuştur (Brown, 2001, 70; Craft, 2012; Daramola, 2015; GrandClement, 2017, 4; Third vd., 2017). Bununla birlikte, Avrupa ülkelerinde dâhi dijital ortama erişim noktasında önemli boşluklar ve tutarsızlıklar, yapısal eşitsizlikler ile önemli farklılıklar bulunduğu düşünülmektedir (Sefton-Green vd., 2016, 3).

Teknoloji mevcut topluma büyük faydalar sağlamış olsa da, insanların teknolojiyi kullanma biçimlerinin bazı açılardan insanlıklarını baltaladığına dair belirtiler olduğunu iddia eden yaklaşımlar da vardır (Yamamoto ve Ananou, 2015). Öyle ki bazı yaklaşımlara göre, teknoloji günlük hayatımızı kolaylaştırırken çocuklar için tehlikeli olabildiği için yakından izlenmelidir (Huntington, 2013, 134). Kuşkusuz yeni medya bağlamında medya etkileri paradigmasının yeniden gözden geçirilmesi gerekmektedir (Valkenburg ve Peter, 2013).

Geleneksel medyanın toplumsal hayata etkisi göz ardı edilemezken, bugün iletişim teknolojileri ve internet temelinde gelişen bir alan olan "yeni medya" birçok alanda toplumsal yapıyı, yaşamı etkilemektedir. Medya etkileri ile ilgili güçlü etkiler başta olmak üzere farklı yaklaşımlar ortaya konsa da (Neuman ve Guggenheim, 2011, 169) medya işlevleri konusunda benzer bir yaklaşım olduğu söylenebilir. Bu işlevler arasında; medyanın insanlar tarafından talep edilen haber ve bilgileri sağlaması, halkı eğitmesi, eğlendirmesi, demokrasiye etkili biçimde yardımcı olması, idarenin politika ve programları konusunda kamuoyunu bilgilendirmesi, kamuoyunun istek ve tepkilerini dile getirmesi, yürütmenin politika ve programlarında değişiklik yapmasına yardımcı olması vardır. Gelişim ve değişimin aracı olması, ulusal ve küresel olarak insanları yakınlaştırması, reklamlarla ticareti desteklemesi, demokratik süreçlere ve sosyal değişime yardımcı olması bu işlevlerdendir (Mehraj, 2014, 57; Dönmezer, 1983, 6-7; McQuail, 1994, 42; İçel, 1983, 51; Kaya, 1985, 16).

"Sosyal medya" olgusu ise bugünlerde tüketicilerin internette sosyal etkileşime girmeleri için de yeni firsatlar sağlamıştır (Hajli, 2014, 387). Sosyal medya, insanların içerik oluşturduğu, paylaştığı ve yer işareti eklediği bir çevrimiçi söylem kategorisi olarak adeta patlamıştır (Owusu-Acheaw ve Larson, 2015). Sosyal 
medya elektronik metinlerin, grafiklerin, hareketli görüntülerin ve seslerin bir araya getirilmesi de dâhil olmak üzere, dijital medyanın insanlara uygun amaçlar için veri ile etkileşime girmesini sağlayan yapılandırılmış bilgisayar ortamına entegre edilmesidir (Njoroge, 2013, 8).

Sanal ağlarda kullanıcıların kendi aralarında içerik oluşturdukları, paylaştıkları ve yorumladıkları kişiler arasındaki etkileşimlerin araçları olan sosyal medya ya da "sosyal ağ" neredeyse günlük hayatımızın bir parçası haline gelmiştir. Gazete, radyo ve televizyon gibi geleneksel kitle iletişim araçları ile benzeşen sosyal medya etkileşim, diyaloji özelliği ile bilgi ve fikirlerin paylaşılmasından çok daha fazlasını nitelemektedir. Twitter, Facebook, Flickr ve bloglar gibi sosyal ağ araçları geleneksel medyadan çok daha hızlıdır ve fikirlerin çevrimiçi olarak oluşturulmasını ve paylaşılmasını kolaylaştırmıştır (Shahjahan ve Chisty, 2014).

Sosyal medya popüler haber platformları haline geldikçe, gazeteciler ve haber kuruluşları da kitleleri oluşturma ve sürdürme potansiyellerinden yararlanma konusunda istekli olmuştur. Bununla birlikte, bu çabaların ne ölçüde olumsuz etkileri olabileceği hakkında çok az şey bilinmektedir (Lee, 2015, 312). Ayrıca sosyal medya, insanların yaşam tarzını değiștirmesinde hayati bir rol oynamaktadır (Siddiqui ve Singh, 2016).

\section{Dijital Propaganda ve Twitter}

\subsection{Dijital Propaganda}

Eski dünyanın büyük imparatorlukları, zamanlarının "propaganda ustaları" değildir. Bu niteleme kesinlikle Hıristiyanlığın ve İslam'ın kurucularına dayanmalıdır. Çünkü hem Hz. İsa hem de Hz. Muhammed etkili ikna stratejileri ile "Batı" ve "Doğu"ya hükmedecek hareketlere yol açmışlardır (Ingram, 2016, 89). "Propaganda" kelimesinden türetilen propaganda fikri ve pratiği ise tutumların, imgelerin ve inançların yaratılmasına ve yaygınlaştırılmasına ilişkindir. Propaganda; 20. yüzyılın yaygın bir özelliği, birçokalana dokunan bir uygulama, düşünceyi, algıyı örgütlemenin ve şekillendirmenin merkezi bir aracı olarak yorumlanabilir. Üçüncü Reich ve Soğuk Savaş döneminde istismarlara maruz kalan ve son zamanlarda gerçek olmayan ile eşanlamlı olarak anılan propaganda, yine de hem olumlu hem de olumsuz bir güç olarak görülmüştür (Auerbach ve Castronovo, 2013). Propaganda hiçbir zaman bir bilinmezlikten kaynaklanmaz ve propagandanın daima bir amaç ve tasarısı söz konusudur (Nadir Çetin, 2014, 239-240).

Dijital propaganda ise, propaganda faaliyetlerinin dijital ortamlarda icra edilmesini nitelemektedir. Dijital propaganda, özellikle sosyal ağlarda ve internet ortamlarında yapılmaktadır. Facebook, Twitter bugün etkili dijital propaganda ortamlarıdır ve kitlesellik, hız ve etkileşim bağlamında bir hayli tercih edilmektedir. Çünkü bireyler büyük ölçüde sosyal ağlarda gezinmekte; siyasal, kültürel, toplumsal birçok pratik yürütmektedir.

Dijital propaganda noktasında ilk akla gelen Amerika Birleşik Devletleri (ABD) eski Başkanı Barack Obama'nın faaliyetleridir. Obama'nın seçim zaferinin ardından dijital kanallar aracılığı ile yapılan propaganda faaliyetleri büyük önem, ilgi ve hız kazanmıştır (Akay, 2011). Obama gibi yine geçtiğimiz ABD başkanlık seçimlerinde Hillary Clinton için de yeni medya tabanlı propaganda yapıldığını belirtmek gerekir. Bugün birçok siyasi aktör ve parti propaganda faaliyetleri bağlamında özellikle sosyal 
medyayı - yoğun olarak Facebook ve Twitter'ı - kullanmaktadır. "Ağ propagandası" olarak da tanımlayacağımız sosyal ağlar aracılığı ile yapılan propaganda, kuşkusuz etkileşime olanak tanıdığından ve kitlesel olarak hızla ilerlediğinden, yapısallığı bağlamında olduğu kadar, etkileri bağlamında da ele alınmalıdır. Ağ propagandasının bir diğer önemli özelliği, iddiaların ve ifadelerin tekrarlanması ve böylece mesajların tanınılırlık ve hatırlanabilirliğinin artmasıdır (Farris vd., 2017, 123). Paylaşımlar silinmediği müddetçe de bir arşiv niteliğinde olan sosyal ağlarda propaganda içeriğine devamlı erişim mümkün olmaktadır.

Kimi zaman yalan dâhi söyledikleri, hatta başkalarını kendi adlarına yalan söylemeye zorladıkları iddia edilen siyasi aktörler, bilginin daha çok ve hızlı yayılması adına sosyal ağlarda propagandaya giriștikleri gibi, bilginin manipüle edilmesine de çalışabilmekteler (Little, 2017, 224). Ayrıca çoğu kez taraflılık tartışmalarının ortasında kalan gazeteciler de haber ve içeriğin manipülasyonu bağlamında gerek geleneksel, gerekse yeni medyada propaganda tartışmalarının içerisinde kalabilmektedir. Oysaki gazeteciler işlerinin doğasını ve taleplerini belirleyemedikleri gibi çoğu zaman okurlarının ne istediğini, ne düşündüğünü, neden nefret ettiğini veya korktuğunu da belirlemeyemezler. Çünkü işlerinin doğası ve talepleri, toplumların daha geniş doğası ve üyelerinin inançları, değerleri ve dünya görüşleri tarafından belirlenir (Paul ve Elder, 2004, 27). Buna karşın, özellikle taraflı medya kuruluşları ya da çalışanları sıklıkla seçim dönemlerinde propaganda aktörleri olarak öne çıkabilir. Çünkü siyaset ve medyanın ekonomi politiği arasında yakın bir ilişki vardır.

\subsection{Bir Dijital Propaganda Mecrası Olarak Twitter}

Propagandayı bir tür "söylem" olarak tanımlayan yaklaşımlar da vardır. Propaganda, insanların kendi argümanlarını hiçbir zaman bulamayacakları ve muhalefetin argümanlarını görmeye eğilimli oldukları gibi olumsuz çağrışımlara sahiptir (Walton, 1997). Bu yaklaşımda vurgulanan, aslında propagandanın insan aklına üstünlük kurmaya çalışmasıdır. Geleneksel kitle iletişim araçlarının güçlü ve etkili birer propaganda aracı olduğu konusunda görüş birliği söz konusudur. Buna karşın bugün yeni medya tabanlı sosyal ağlar, platformlar da etkili propaganda mecraları olarak öne çıkmaktadır.

Sosyal medya, haber içeriklerinin yayılması ve politik katılım için etkili bir platformdur. Sosyal medya platformları aynı zamanda, gençlerin politik kimliklerini geliștirdikleri bir alandır. Bunun sebebi bazı ülkelerde Facebook gibi bazı şirketlerin kamusal yaşam için etkin tekel platformlar olmasıdır. Sosyal medya ve özellikle Facebook, toplumun sadece küçük oranlarının sosyal medyaya düzenli olarak eriştiği ülkelerde gazeteciler, sivil toplum liderleri ve siyasi elitler arasındaki siyasi diyaloğun temel altyapısıdır (Woolley ve Howard, 2017). Twitter ise sosyal medya noktasında kamusal bir alan olma özelliği taşımakta ve toplumun hemen her kesimi için güncel olduğu kadar popüler de bir müzakere alanı olmaktadır (Yegen, 2013). Bu yüzden ilgili sosyal ağlarda propaganda faaliyetleri tasarlanmakta ve yürütülmektedir. Çünkü sosyal ağlar propagandayı hızlı, etkili kılmakta; kitleler ile propagandayı yapan kimseler (siyasetçiler, siyasi partiler, çeşitli oluşum ya da örgütler vb.) arasında etkileşime, karşılıklı iletişime imkân tanımaktadır. Ayrıca sosyal ağlar birer müzakere alanı oldukları için propaganda yapan kimselerin bireylerin/hedef kitlenin beklenti, tepki, duygu ve düşüncelerini güncel olarak görme ve anlamalarına yardım etmektedir. 
Propagandanın yapıldığı yollardan birisinin de dijital oyunlar olduğuna dikkat çekilmekte, bir zamanlar Hollywood'un etkili bir propaganda aracı olduğu, günümüzde ise dijital oyunların aynı amaçla kullanıldığı belirtilmektedir. Sadece dijital oyunlar değil, yeni medya tabanlı farklı kanallar aracılığı ile de propaganda faaliyetlerinin geliştirildiği görüşü vardır (haberler.com, 22.05.2017). Richard Nixon'ın "propaganda ve bilgiye yatırılmış 1 doların silah sisteminin oluşturulmasına yatırılan 10 dolardan daha değerli" olduğunu görüşü hatırlandığında, propaganda bağlamında bilgi ve iletişime atfedilen önem (Camankulova, 2013, 102) çok daha iyi anlaşılmaktadır.

Twitter ve Facebook gibi küresel sosyal ağlarda çoğunlukla siyasi parti ve aktörlerin politik propaganda faaliyetlerinin yürütülmesi yanında, farklı oluşum ve örgütlerin propaganda faaliyetleri de gözlenmektedir. Örneğin Küresel Cihatçı Hareket'in, ideolojilerinin merkezi noktalarını oluşturan, iyi tanımlanmış bir dizi hedefe sahip olduğu iddia edilmektedir ve bu hedeflerin gerçekleştirilmesinde propaganda ve kamu iletişimi merkezi bir rol oynamaktadır (Torres vd., 2006). Bu yüzden hareket, propaganda için sıklıkla sosyal medyayı kullanmaktadır. Bu şekilde; yeni üyeler toplama, muhaliflerini sindirme ve meşruiyetini tanıtma amaçlanmaktadır (William, 2016).

Twitter'da ayrıca beyaz propaganda yapmayı amaçlayan çeşitli ulusal ve uluslararası oluşum, örgüt ya da alternatif medya kuruluşları da etkin şekilde propaganda faaliyetleri yürütmektedir. Bunlarla ilgili; Greenpeace (@Greenpeace),TEMAVakfi (@ temavakfi), Dünya Doğayı Koruma Vakfı Türkiye (WWF Turkey) (@WWF_TURKIYE), Dünya Sağlık Örgütü (World Health Organization (WHO) (@WHO) gibi oluşumlar ile Diken (@DikenComTr) ve Dokuz8HABER (@dokuz8haber) gibi alternatif medya kuruluşları güncel örnekler olarak verilebilir.

\section{24 Haziran Seçimleri ve Adayların Dijital Propaganda Çalışmaları Üzerine Bir Analiz}

Türkiye, 16 Nisan 2107'deki referandum ile yapılan Anayasa Değişikliği'nin ardından Cumhurbaşkanlığı Sistemi'ne geçmiştir. Yeni sistem ile birlikte 2019 yılında yapılması planlanan seçimler erkene alınarak, 24 Haziran 2018'de gerçekleşmiştir. Adalet ve Kalkınma Partisi (AK Parti) ile Milliyetçi Hareket Partisi (MHP) tarafından kurulan Cumhur İttifakı'nın gösterdiği aday olan mevcut Cumhurbaşkanı Recep Tayyip Erdoğan, yeni sistemin ilk Cumhurbaşkanı seçilmiştir. Seçimlerde; Cumhuriyet Halk Partisi (CHP) Muharrem İnce'yi, Halkların Demokratik Partisi (HDP) Selahattin Demirtaş’ı aday gösterirken, İYi Parti Genel Başkanı Meral Akşener, Saadet Partisi (SP) Genel Başkanı Temel Karamollaoğlu, Vatan Partisi Genel Başkanı Doğu Perinçek 100 bin imza toplayarak aday olmuştur (sözcü.com.tr, 09.05.2018). Sandıktan çıkan sonuçlara göre adaylardan; Recep Tayyip Erdoğan \% 52,59, Muharrem İnce \% 30,64, Selahattin Demirtaş \% 8,40, Meral Akșener \% 7,29, Temel Karamollaoğlu \% 0,89, Doğu Perinçek \% 0,20 oranında oy almıştır. Aynı tarihte yapılan milletvekili seçimlerinde ise; AK Parti \% 42,56, CHP \% 22,65, HDP \% 11,70, MHP \% 11,10, İYİ Parti \% 9,96, SP \% 1,34, HÜDAPAR \% 0,31 ve Vatan Partisi \% 0,23 oy oranına ulaşmıştır (Yüksek Seçim Kurulu (YSK), 2018).

Seçim kampanyası süresince Cumhurbaşkanı adayları ve siyasi partiler diğer mecralar kadar sosyal ağlarda da etkili propaganda faaliyetleri yürütmüş, özellikle Twitter dijital bir propaganda mecrası olarak öne çıkmıştır. Twitter'ın dijital bir propaganda mecrası olarak siyasi aktörler tarafından kullanılması bu çalışmada ele alınmaktadır. 
Çalışma çerçevesinde 24 Haziran 2018 seçimlerine katılan Cumhurbaşkanı adayları ve siyasi partilerin Twitter platformundaki sosyal ağları incelenmiş ve politik başarı durumları ele alınmıştır.

\subsection{Yöntem}

24 Haziran 2018 tarihinde gerçekleştirilen Cumhurbaşkanlığı ve 27. Dönem Milletvekili seçim kampanyaları kapsamında Cumhurbaşkanı adayları ve siyasal partilerin Twitter üzerinde yürütülen propaganda faaliyetleri sosyal ă̆ analizi yöntemi ile incelenmiștir. Sosyal ağ analizi insanlar, gruplar, kurumlar gibi olgular arasındaki ilişki ve akışı haritalamak ve ölçmektir. Ağdaki düğümler insanlar ve bağlantılar arasındaki ilişkileri gösterir. Sosyal ağ analizi, insan ilişkilerinin hem görsel hem de matematiksel analizine olanak tanır (Butts, 2008; Jamali ve Abolhassani, 2006).

Çalışmanın veri seti, Yüksek Seçim Kurulu'nca (YSK) Cumhurbaşkanı adaylarının resmen açıklandığı 9 Mayıs 2018 ile seçimlerin yapıldığı 24 Haziran 2018 tarihleri arasında Twitter üzerindeki propaganda faaliyetlerini içermektedir. Çalışma, belirtilen tarih aralığında ve Tablo 1'de gösterilen siyasi parti ve Cumhurbaşkanı adaylarının Twitter üzerindeki hesaplarının oluşturduğu sosyal ağlar ile sınırlıdır.

Tablo 1: Çalışmanın Örneklemini Oluşturan Twitter Hesapları

\begin{tabular}{|l|l|l|l|}
\hline \multicolumn{2}{|c|}{ Siyasi Partiler (Veri Seti 1) } & \multicolumn{2}{c|}{ Cumhurbaşkanı Adayları (Veri Seti 2) } \\
\hline Adı & Twitter Hesap Adı & Adı & Twitter Hesap Adı \\
\hline Adalet ve Kalkınma Partisi (AK Parti) & @akparti & Muharrem İnce & @vekilince \\
\hline Milliyetçi Hareket Partisi (MHP) & @mhp_bilgi & Meral Akşener & @meral_aksener \\
\hline Hür Dava Partisi (HÜDAPAR) & @hurdavapartisi & Recep Tayyip Erdoğan & @rt_erdogan \\
\hline Vatan Partisi (VATAN) & @vatan_partisi & Selahattin Demirtaş & @hdpdemirtas \\
\hline Halkların Demokrasi Partisi (HDP) & @hdpgenelmerkezi & Temel Karamollaoğlu & @t_karamollaoglu \\
\hline Cumhuriyet Halk Partisi (CHP) & @herkesicinchp & Doğu Perinçek & @dogu_perincek \\
\hline Saadet Partisi (SP) & @saadetpartisi & & \\
\hline İyi Parti (IYi Parti) & @iyiparti & & \\
\cline { 1 - 2 }
\end{tabular}

Çalışmada veriler, Cumhurbaşkanı adayları ve siyasi partiler için iki farklı veri seti şeklinde NodeXL yazılımı ile toplanmıștır. Veri setinde örnekleme dâhil edilen hesapların ego ağlarındaki aktörler, bu aktörler arasındaki bağlantılar, retweet'ler, takipçi miktarları ve gönderi içerikleri bulunmaktadır. Verilerin analizinde öncelikle sosyal ağın genel ölçütleri (aktör sayısı, bağlantı sayısı, yoğunluk vb.) hesaplanmıştır. Daha sonra merkeziyet ölçütleri (out-degree- in-degree, beetwenness centrality) hesaplanmıştır. Merkezilik bir ağdaki bir düğümün konumunun özelliğidir (Borgatti vd., 2013). Aktörler ağda farklı yapısal konumlara sahiptir. Bu konumlar, aktörlerin ağda oynadığı rolleri anlamamıza yardımcı olurlar. Bu aktörleri tanımlamak için merkezilik ölçütleri kullanılır. Merkeziyet ölçütleri genellikle güç, etki, popülerlik ve prestij göstergeleri olarak kullanılmıștır (Scott ve Carrington, 2011). Yönlü ağlarda iç-derece merkeziliği bir anlamda bireyin sosyal ağlardaki popülerliğini, ün ve prestijini, dış-derece merkeziliği ise bireyin sokulganlık ve sosyalleşebilirliğini göstermektedir (Tunalı, 2016). Arasındalık merkeziliği bir aktörün, diğer aktörleri birbirine bağlayan en kısa yollarda bir aracı pozisyonunu işgal ederek, ağdaki diğer aktör çiftleri için bir "potansiyel” olarak görev yapmasıdır (Kilduff ve Tsai, 2003). Tipik olarak, yüksek arasındalık değerine sahip olan bir aktör, sosyal ağda akan 
bilgi üzerinde yüksek bir kontrol seviyesine sahiptir. Bu aktör genellikle eşik bekçisi rolündedir (Pryke, 2012).

Çalışmada farklı bulgulara ulaşılmaya çalışılmıştır. Twitter platformundaki siyasi parti ve Cumhurbaşkanı adaylarına ait ağların; genel yapısı (aktör ve bağlantı miktarı vb.), konumu, konum ile politik bașarı arasındaki ilişki, diğer aktörlerle bağlantı miktarı, retweet ${ }^{2}$ ve takipçi miktarları ile politik başarısı arasındaki ilişkinin belirlenmesi bunlar arasındadır. Bu bağlamda çalışmanın araştırma hipotezleri aşağıdaki gibidir:

- H1: Siyasi partiler ağında arasındalık ölçütü ve retweet miktarı arasında anlamlı bir ilişki vardır.

- H2: Siyasi partiler ağında bağlantı miktarı ve retweet miktarı arasında anlamlı bir ilişki vardır.

- H3: Siyasi partiler ağında takipçi miktarı ve retweet miktarı arasında anlamlı bir ilişki vardır.

- H4: Siyasi partiler ağında arasındalık ölçütü ve politik başarı arasında anlamlı bir ilişki vardır.

- H5: Siyasi partiler ağında bağlantı miktarı ve politik başarı arasında anlamlı bir ilişki vardır.

- H6: Siyasi partiler ağında takipçi miktarı ve politik başarı arasında anlamlı bir ilișki vardır.

- H7: Siyasi partiler ağında retweet miktarı ve politik başarı arasında anlamlı bir ilişki vardır.

- H8: Cumhurbaşkanı adayları ağında arasındalık ölçütü ve retweet miktarı arasında anlamlı bir ilişki vardır.

- H9: Cumhurbaşkanı adayları ağında bağlantı miktarı ve retweet miktarı arasında anlamlı bir ilişki vardır.

- H10: Cumhurbaşkanı adayları ağında takipçi miktarı ve retweet miktarı arasında anlamlı bir ilişki vardır.

- H11: Cumhurbaşkanı adayları ağında arasındalık ölçütü ve politik başarı arasında anlamlı bir ilişki vardır.

- H12: Cumhurbaşkanı adayları ağında bağlantı miktarı ve politik başarı arasında anlamlı bir ilişki vardır.

- H13: Cumhurbaşkanı adayları ağında takipçi miktarı ve politik başarı arasında anlamlı bir ilişki vardır.

- H14: Cumhurbaşkanı adayları ağında retweet miktarı ve politik başarı arasında anlamlı bir ilişki vardır. 


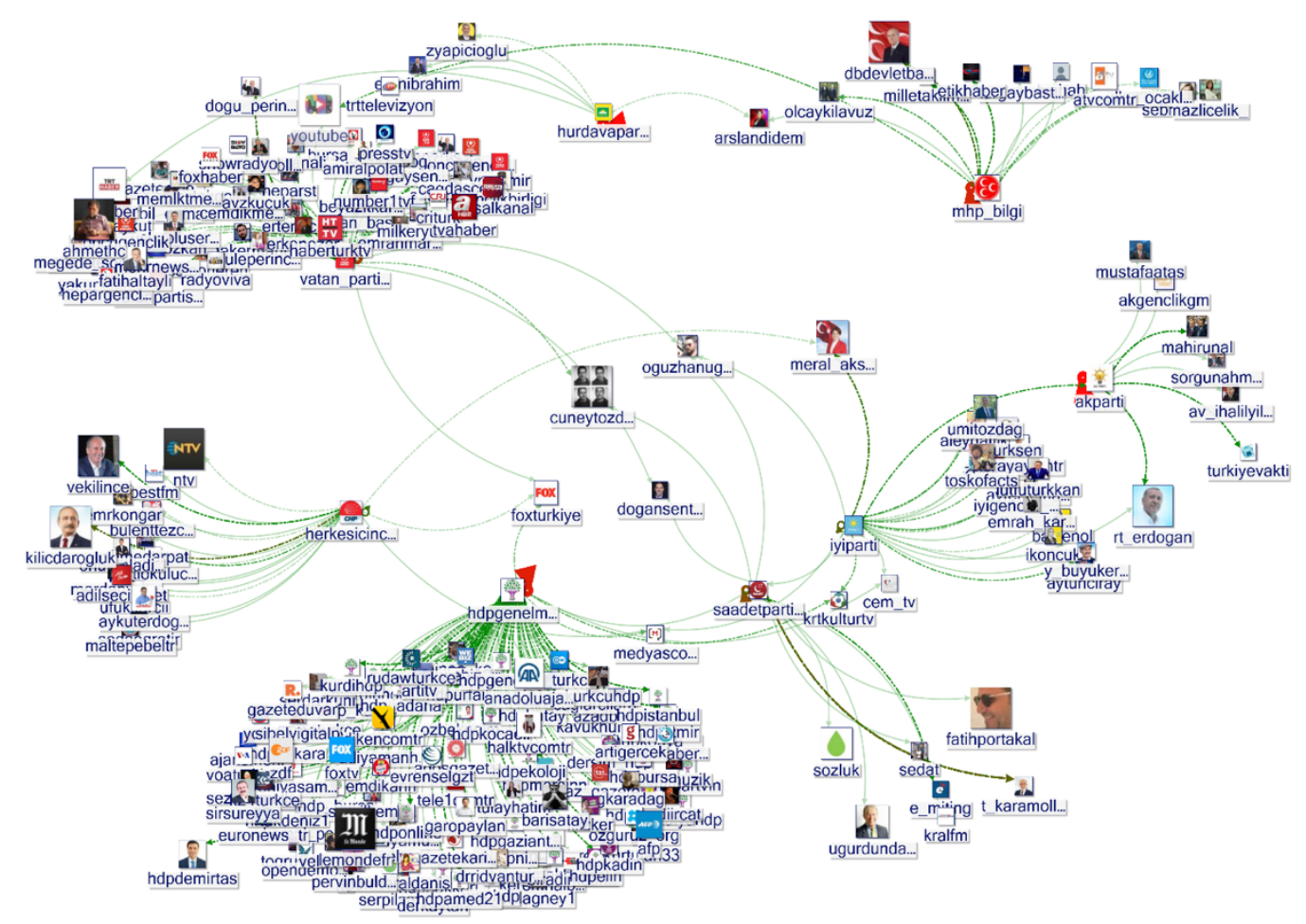

Şekil 1: Siyasi Partilerin Ağ Görseli

\subsection{Bulgular}

\subsubsection{Siyasi Partiler: Ağın Genel Yapısı}

24 Haziran 2018 tarihinde gerçekleştirilen Milletvekili seçimlerine 8 siyasi parti katılmıştır. Dolayısıyla ilk veri seti 8 siyasi partinin iç ve dış bağlantılarının oluşturduğu sosyal ağa aittir. Siyasi partilerin oluşturduğu sosyal ağı temsil eden görsel Şekil 1'de yer almaktadır.

Belirtilen tarihlerde, seçimekatılan siyasi partilerin Twitterüzerindekibağlantılarının oluşturduğu ağda 223 aktör bulunmaktadır. Bu aktörler arasında 6.621 bağlantı gerçekleșmiștir. Sosyal ağın yoğunluğu ise 0,004 olarak hesaplanmıștır. Bu sonuca göre, aktörler arasında gerçekleşebilecek bağlantı sayısının binde dördü kadar bir ağ yoğunluğu bulunmaktadır.

\subsubsection{Siyasi Parti Ağının Merkeziyet Ölçütleri}

Siyasi partilerin oluşturduğu ağdaki konumlarını gösteren merkeziyet ölçütleri (Tablo 2) değerlendirildiğinde, arasındalık ölçütü HDP'nin diğer partilere göre aktörleri birbirine bağlayan en kısa yollarda daha yüksek bir değerle $(34234,286)$ bir aracı pozisyonunda ve akan bilgi üzerinde yüksek bir kontrol seviyesine sahip olduğu görülmektedir. Yine ağdaki iç ve dış aktör bağlantı değerlerinin gösterdiği sonuçlara göre, Twitter'daki en sosyal partinin HDP olduğu ortaya çlkmaktadır. $\mathrm{Bu}$ siralamayı VATAN Partisi ve IYYI Parti izlemektedir. Tablo-2'de arasındalık ölçütüne göre siyasi partilerin sıralaması bulunmaktadır. HDP ağdaki bu konumuyla bağlantıların \% 20'sini gerçekleștirmiştir. Bu bağlantılar (1.327) başka hesaplarca 269.443 kez retweet edilmiştir. Analizler neticesinde öne çlkan bir diğer sonuç AK Parti ile ilgilidir. AK Parti ağdaki konumuyla diğer partilere göre daha fazla oranda, yani bağlantıların \% 23'ünü gerçekleştirmiş ve 857.772 retweet ile sosyal ağ üzerinden bilgiyi yayabilmiştir. Başka bir deyişle AK Parti'nin 1.523 bağlantısı 
857.772 Twitter hesabı tarafından tekrar paylaşılarak ağda yayılım sağlanmıştır. Yine politik bilginin yayılımında IYI Parti (621.902) ve MHP (551.663) aldıkları değerlerle öne çıkmaktadır.

Tablo 2: Siyasi Partilerin Merkeziyet Ölçütleri ve Politik Başarı

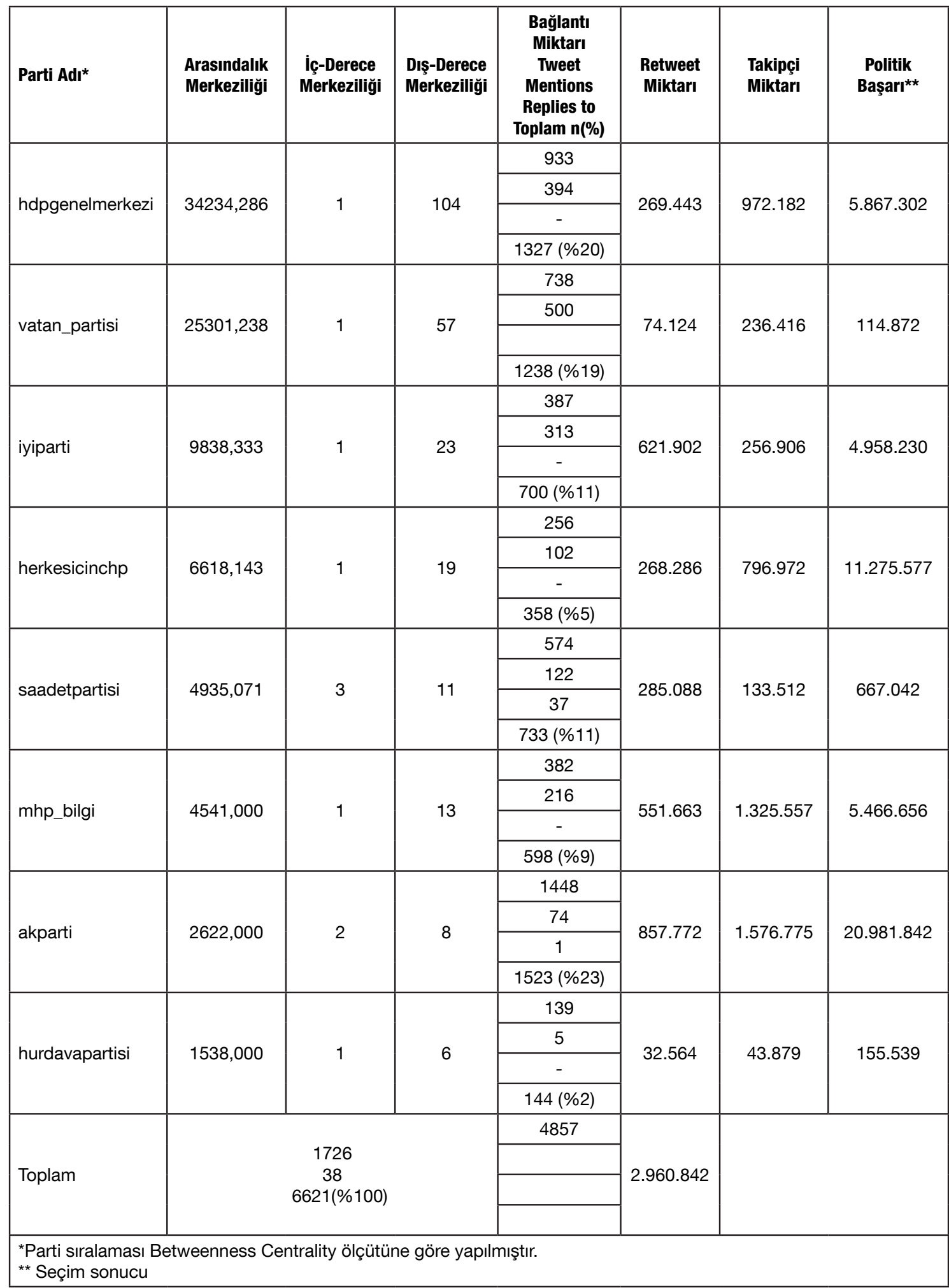

$\mathrm{Bu}$ bulgular, Twitter özelinde sosyal ağların propaganda aracı olarak işlevselliğini ortaya koymuştur. Bu bulgulara ek olarak, arasındalık ölçütü, bağlantı sayısı ve takipçi sayıları ile retweet ve politik başarı arasında öngörülen ilişkilerin anlamlı olup olmadığı doğrusal regresyon analizi ile test edilmiştir (Şekil-2). 


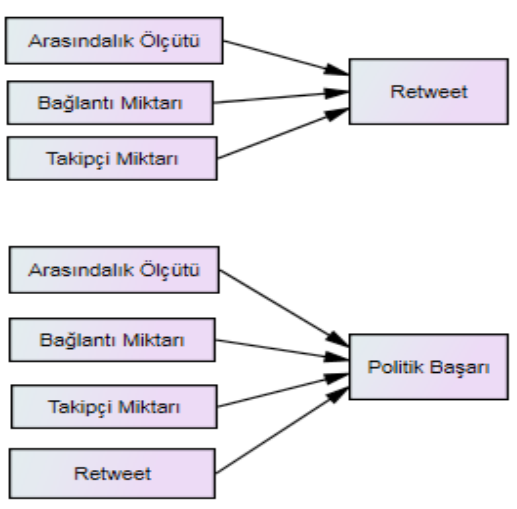

Şekil 2: Araştırma Modeli

Analiz neticesinde ilk olarak, siyasi partilerin arasındalık ölçütü, bağlantı miktarı ve takipçi miktarı ile retweet miktarı arasında doğrusal bir ilişki olmadığı belirlenmiştir ( $p$ > 0.05). Daha sonra, bağlantı sayısı, takipçi sayısı ve retweet ile politik başarı arasında doğrusal bir ilişki olmadığı tespit edilmiştir ( $p>0.05)$. Bu sonuçlara göre siyasi partiler ağında arasındalık ölçütü, bağlantı ve takipçi miktarları ile retweet miktarı; yine aynı merkeziyet ölçütleriyle retweet miktarı ile politik başarı arasında ilişki öngören 1, 2, 3, 4, 5, 6, 7 numaralı hipotezlerin kabul edilmediği söylenebilir.

\subsubsection{Cumhurbaşkanı Adayları: Ağın Genel Yapısı}

24 Haziran 2018 tarihinde gerçekleştirilen Cumhurbaşkanlığı seçimlerine partilerin grup kararıyla üç aday ve yüzbin seçmenin imzası ile üç aday olmak üzere altı aday katılmıştır. Cumhurbaşkanı adaylarının propagandalarına dair sosyal ağı temsil eden görsel Şekil 3'tedir. Politik aktörlerin iç ve dış bağlantılarından oluşan ağda 1.135 aktör bulunmaktadır. Bu aktörler arasında 16.675 bağlantı gerçekleşmiştir. Sosyal ağın yoğunluğu ise 0,0009 olarak hesaplanmıștır. Bu sonuca göre, aktörler arasında gerçekleşebilecek bağlantı sayısının on binde dokuzu kadar bir ağ yoğunluğu bulunmaktadır. Seçim döneminde Twitter üzerinde siyasi partilere nazaran politik adaylar daha fazla bağlantı yapısına sahiptir.

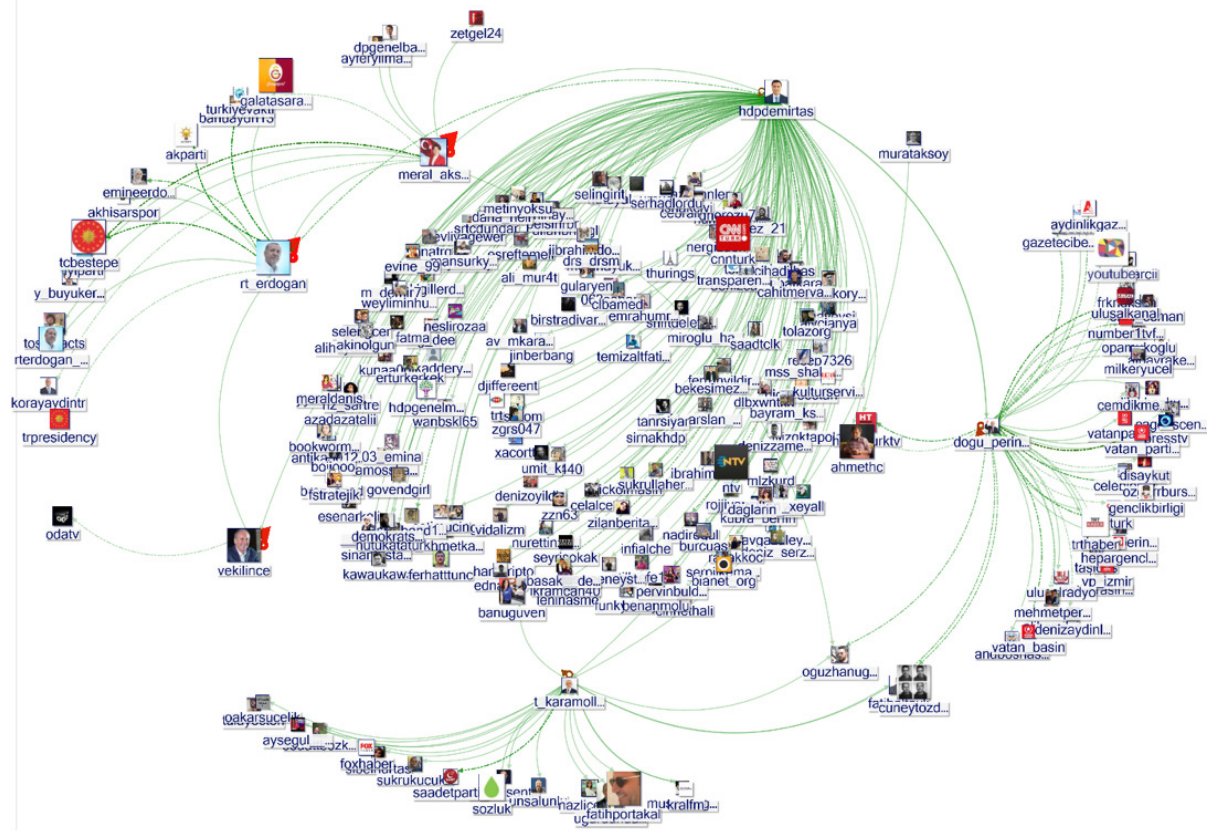

Şekil 3: Cumhurbaşkanı Adaylarının Ağ Görseli 


\subsubsection{Cumhurbaşkanı Adayları Ağının Merkeziyet Ölçütleri}

Cumhurbaşkanı adaylarının oluşturduğu ağdaki konumlarını gösteren merkeziyet ölçütleri (Tablo 3) değerlendirildiğinde, Doğu Perinçek Twitter hesabının arasındalık ölçütü değeri diğer adaylara göre en yüksek değere $(680385,172836)$ sahiptir. Bu sıralamayı Selahattin Demirtaş ve Muharrem İnce takip etmektedir. Yine ağdaki iç ve dış aktör bağlantı değerlerinin benzer şekilde sıralandığı söylenebilir.

Ağdaki bağlantı oranlarına göre bir sıralama ise Meral Akşener (\% 29), Selahattin Demirtaş (\% 20) ve Muharrem İnce (\% 20) şeklindedir. Ancak politik bilginin yayılmasında referans alabileceğimiz retweet değerleri, Muharrem İnce (2498970) ve Recep Tayyip Erdoğan'ın (1134015) paylaşımlarında daha fazla gerçekleşmiştir.

Tablo 3: Cumhurbaşkanı Adayları Merkeziyet Ölçütleri ve Politik Başarı

\begin{tabular}{|c|c|c|c|c|c|c|c|}
\hline Aday* & $\begin{array}{l}\text { Arasındalık } \\
\text { Merkeziliği }\end{array}$ & $\begin{array}{l}\text { İç-Derece } \\
\text { Merkeziliği }\end{array}$ & $\begin{array}{l}\text { Dış-Derece } \\
\text { Merkeziliği }\end{array}$ & $\begin{array}{c}\text { Bağlantı } \\
\text { Miktarı } \\
\text { Tweet } \\
\text { Mentions } \\
\text { Replies to } \\
\text { Toplam } \\
\text { n(\%) }\end{array}$ & $\begin{array}{l}\text { Retweet } \\
\text { Miktarı }\end{array}$ & $\begin{array}{l}\text { Takipçi } \\
\text { Miktarı }\end{array}$ & $\begin{array}{c}\text { Politik } \\
\text { Başarı** }^{\star 2}\end{array}$ \\
\hline \multirow{4}{*}{$\begin{array}{l}\text { dogu_ } \\
\text { perincek }\end{array}$} & \multirow{4}{*}{680385,172836} & \multirow{4}{*}{2} & \multirow{4}{*}{385} & 138 & \multirow{4}{*}{47.078} & \multirow{4}{*}{206.843} & \multirow{4}{*}{98.955} \\
\hline & & & & 89 & & & \\
\hline & & & & - & & & \\
\hline & & & & $227(\% 11)$ & & & \\
\hline \multirow{4}{*}{ hdpdemirtas } & \multirow{4}{*}{644443,685307} & \multirow{4}{*}{2} & \multirow{4}{*}{333} & 251 & \multirow{4}{*}{813.636} & \multirow{4}{*}{1.694 .784} & \multirow{4}{*}{4.205 .794} \\
\hline & & & & 156 & & & \\
\hline & & & & - & & & \\
\hline & & & & 407 (\%20) & & & \\
\hline \multirow{3}{*}{ vekilince } & \multirow{3}{*}{369401,939514} & \multirow{3}{*}{2} & \multirow{3}{*}{201} & 404 & \multirow{3}{*}{2.498 .970} & \multirow{3}{*}{4.675 .286} & \multirow{3}{*}{15.340 .321} \\
\hline & & & & 2 & & & \\
\hline & & & & $406(\% 20)$ & & & \\
\hline \multirow{4}{*}{$\begin{array}{l}\text { meral_ } \\
\text { aksener }\end{array}$} & \multirow{4}{*}{356121,318986} & \multirow{4}{*}{2} & \multirow{4}{*}{191} & 575 & \multirow{4}{*}{691.191} & \multirow{4}{*}{2.750 .149} & \multirow{4}{*}{3.649 .030} \\
\hline & & & & 21 & & & \\
\hline & & & & 2 & & & \\
\hline & & & & 598 (\%29) & & & \\
\hline \multirow{4}{*}{ rt_erdogan } & \multirow{4}{*}{173854,726887} & \multirow{4}{*}{5} & & 156 & & & \\
\hline & & & 76 & 34 & 1.134 .015 & 13.160 .094 & 26.330 .823 \\
\hline & & & & - & & & \\
\hline & & & & $190(\% 9)$ & & & \\
\hline & & & & 223 & & & \\
\hline & 38296901997 & 3 & 29 & 25 & 320.977 & 284349 & 443704 \\
\hline karamollaoglu & 38290,901991 & & 29 & - & & & 443.104 \\
\hline & & & & $248(\% 12)$ & & & \\
\hline & & & & 1747 & & & \\
\hline & & & & 327 & & & \\
\hline Toplam & & & & 2 & 5.505 .867 & & 50.058 .220 \\
\hline & & & & $\begin{array}{c}2076 \\
(\% 100)\end{array}$ & & & \\
\hline
\end{tabular}


Cumhurbaşkanı adaylarına ait değerler için doğrusal regresyon analizi ile bu ilişkilerin anlamlı olup olmadığı test edilmiştir. Çoklu regresyon analizi sonuçları Tablo 4'te yer almaktadır. Regresyon analizinden elde edilen bulgular arasındalık ölçütü, bağlantı ve takipçi miktarları ile retweet arasında doğrusal bir ilişki öngören 8, 9, 10 numaralı hipotezlerin kabul edilmediğini ortaya koymuştur ( $\mathrm{p}>0.05$ ). $\mathrm{Bu}$ sonuca ek olarak, regresyon denklemine giren değerler açısından arasındalık merkeziyetinin ( $\beta=.027, p>$.05) politik başarıyı yordamada anlamlı olmadığı tespit edildiğinden, 11 numaralı hipotez kabul edilmemiştir. Ancak bulgular, bağlantı miktarı, takipçi miktarı ve retweet değerlerinin doğrusal kombinasyonunun adayın politik başarısını yordadığını göstermiştir $\left(\mathrm{R}^{2}=.05, \mathrm{~F}=20252.831, \mathrm{p}<.05\right) . \mathrm{Bu}$ ilişkide takipçi ve retweet miktarında bir birim artışın; bağlantı miktarında ise bir birim azalmanın anlamlı șekilde politik başarıyı yordadığı görülmektedir. Bu sonuç 12, 13, 14 numaralı hipotezlerin doğrulandığını ortaya koymaktadır.

Tablo 4: Cumhurbaşkanı Adayların Politik Başarısını Yordayan

Değişkenler Açısından Çoklu Regresyon Analizi Sonuçları

\begin{tabular}{|l|c|c|c|c|c|}
\hline Değişkenler & B & SH & $\boldsymbol{\beta}$ & $\mathbf{t}$ & $\mathbf{p}$ \\
\hline Arasındalık Merkeziyeti & 1,110 &, 157 &, 027 & 7,062 &, 090 \\
\hline Takipçi Sayısı & 1,726 &, 010 &, 809 & 179,314 &, 004 \\
\hline Bağlantı Sayısı & $-7897,139$ & 271,870 &,- 117 & $-29,048$ &, 022 \\
\hline Retweet & 3,779 &, 052 &, 313 & 73,318 &, 009 \\
\hline
\end{tabular}

Elde edilen bulgulara göre, Cumhurbaşkanı adaylarının Twitter üzerindeki takipçi miktarı, bağlantı miktarı ve retweet miktarlarının adayın politik başarısı üzerinde bir belirleyiciliğe sahip olduğu sonucuna varılabilir.

\section{Sonuç ve Değerlendirme}

Propagandaya yönelik ikna ve inandırma stratejilerinin yoğun olarak sosyal ağlarda icra edilmesi, bugün önemli tartışma konularındandır. Siyasi parti ve aktörler kadar, çeşitli örgüt ve oluşumlar için de etkili ve etkileșimli bir propaganda mecrası olan sosyal paylaşım platformlarından Twitter'ın dikkat çektiği söylenebilir. Twtitter'ın diyalojik iletişime olanak tanıyan yapısı gibi, kitlesellik özelliği ve gün geçtikçe popüler olması da siyasi aktörlerin ilgili platformu dijital propaganda aracı olarak seçmesinde kuşkusuz etkili olmuştur. Bu çerçevede çalışmada elde edilen sonuçlara bakıldığında, ilk olarak Amerika Birleşik Devletlerindeki seçimlerde olduğu gibi, Türkiye'de de seçimler özelinde politik aktörlerce bir siyasi gündemin çevrimiçi ağlarda oluşturulabildiği dikkati çekmektedir. Twitter özelinde hem siyasi partiler, hem de adayların oluşturduğu ağlarda binleri bulan bağlantı sayıları ve milyonları bulan retweet miktarları bizi bu sonuca ulaștırmaktadır. Bu sonuç propagandanın doğasına uygun bir biçimde ağda seçimle ilgili içeriklerin hızla yayıldığını, kullanıcıların retweet'leriyle içerikleri tekrartekrar ağda dolaşıma soktuğu ve böylece propaganda içeriğinin tanınırlığının ve hatırlanabilirliğinin arttığını gösterebilir. Ayrıca, hem siyasi partiler hem de adayların ağdaki konumları (arasındalık, iç ve dış derece ölçütlerine göre) açısından ortaya çıkan sıralamalar incelendiğinde Twitter platformunun tüm aktörlerin kitlelere ulaşabilmesi bağlamında geleneksel medyaya bir alternatif role sahip olduğu bu araştırmanın bir sonucu olarak karşımıza çıkmaktadır. Çalışmanın diğer sonuçlarına, bazı araştırma hipotezlerinin test edilmesi neticesinde ulaşılmıştır. Bu sonuçlar siyasi parti ve Cumhurbaşkanı adaylarının sosyal ağdaki konumları, takipçi, bağlantı ve retweet miktarları ile politik 
başarıları arasındaki ilişkilere yöneliktir. Hipotez testlerine göre siyasi parti veya Cumhurbaşkanı adaylarının ağdaki paylaşımlarının diğer kullanıcılar tarafından retweet yapılması ile ağdaki konum, bağlantı sayısı ve takipçi miktarı arasında bir ilişkinin olmadığı görülmüştür. Bu sonuca ek olarak siyasi partiler için söylenemese de, Cumhurbaşkanı adaylarının politik başarısını Twitter' daki takipçi, bağlantı ve retweet miktarlarının yordadığına yönelik bir sonuca ulaşılmıştır. Siyasi partiler için geçerli olmasa da adayların çevrimiçi propaganda faaliyetlerinin seçim sonucunda elde edilen politik başarı üzerinde bir belirleyiciliği bulunmaktadır. Sonuçlar genel olarak değerlendirildiğinde, çalışma, politik propaganda bağlamında çevrimiçi sosyal ağların kullanımının önemini ortaya koysa da diğer birçok değişkenin (imajlar, geleneksel medya, gündemler, kamuoyu araştırmaları, tutumlar, mesaj içerikleri vb.) politik başarı üzerindeki belirleyiciliğinin unutulmaması gerektiği belirtilmelidir.

\section{Notlar}

${ }^{1}$ Dijital yerliler, dijital çağa doğan bireyleri refere eder. Çocuklar ve gençler bugün dijital yerlileri niteler. Dijital yerliler, günümüzde dijital olan dilin (videolar, bilgisayar oyunları, sosyal ağlar vb.) "yerli konuşucuları"dır. Dijital göçmenler ise dijital çağa ayak uydurmak adına çeşitli faaliyetlerde bulunun bireyleri refere eder. Dijital göçmen çevreye ayak uydurmak ya da sosyalleşmek gibi gerekçeler ile dijital çağda yer alır (Prensky, 2001).

2 "Retweet" bir kullanıcının bir başka kullanıcının tweet'ini, paylaşımını kendi Twitter hesabında yayınlamasıdır (https://medyasyon.wordpress.com, 06.12.2009).

\section{Kaynaklar}

Akay, R. A. (2011). Güncel Türk Siyasal Yaşamında "Siyasal İletişim Danışmanı" Kavramı, Doktora Tezi, T.C. Marmara Üniversitesi Sosyal Bilimler Enstitüsü, İstanbul.

Auerbach, J. \& Castronovo, R. (2013). The Oxford Handbook of Propaganda Studies, OUP USA.

Austin, F. M. (1941). Political Propaganda, British Journal of Educational Psychology, 11 (2): 143-147.

Bartlett, J. \& Miller, C. (2011). Truth, lies and the internet a report into young people's digital fluency, DEMOS, Truth, Lies and the Internet.

Bernays, E. (2005). Propaganda, Introduction by M. C. Miller, Ig Publishing, USA.

Borgatti, S. P., Everett, M. G., \& Johnson, J. C. (2013). Analyzing Social Networks, Sage Publications.

Brown, J. S. (2001). Learning in the Digital Age, The Internet and the University: Forum: 71-72.

Butts, C. T. (2008). Social network analysis: A methodological introduction, Asian Journal of Social Psychology (2008), 11, 13-41.

Camankulova, R. (2013). Kırgız Belgesel Sinemasında Propaganda, İdil 2 (6): 100121.

Childs, P. (2008). Modernism, $2^{\text {nd }}$ Edition, Routledge: Taylor \& Francis Group.

Clark, T. (2017). Sanat ve Propaganda, 3. Baskı, Çev. Esin Hoşsucu, Sanat ve Kuram Dizisi, Ayrıntı Yayınları.

Conserva, H. T. (2003). Propaganda Techniques, Author House. 
Craft, A. (2012). Childhood in a Digital Age: creative challenges for educational futures, Submitted to London Review of Education, August 2011, Revisions submitted to London Review of Education, Accepted for publication March 2012.

Cull, N. J., Culbert, D. \& Welch, D. (2003). Propaganda and Mass Persuasion - A Historical Encyclopedia 1500 to the Present, ABC-CLIO.

Daramola, D. (2015). Young Children as Internet Users and Parents Perspectives, University of Oulu Department of Information Processing Science, Master's Thesis May 18, 2015.

Domenach, J-M. (2003). Politika ve Propaganda, Varlık Yayınları: İstanbul.

Doob, W. (1950). Goebbels' Principles of Propaganda, The Public Opinion Quarterly, 14 (3): 419-442.

Dönmezer, S. (1983) "Basın Suçlarında Ceza Sorumluluğu", Basın ve Basının Karşılaştığı Hukuki Sorunlar, Hürriyet Vakfı Eğitim Yayınları, No.3, İstanbul.

Ellul, J. (1973). Propaganda: The Formation of Men's Attitudes, Vintage Books Edt. USA.

Faris, R. M., Hal R., Etling, B., Bourassa, N., Zuckerman, E. \& Benkler, Y. (2017). Partisanship, Propaganda, and Disinformation: Online Media and the 2016 U.S. Presidential Election, Berkman Klein Center for Internet \& Society Research Paper.

Grand-Clement, S. (2017). Digital learning Education and skills in the digital age, An overview of the consultation on digital learning held as part of the Corsham Institute Thought Leadership Programme 2017.

Güz, N. (2005). Haberde Yönlendirme ve Kamuoyu Araştırmaları, Nobel Yayıncılık: Ankara.

Haberler. (2017). "Bakan Kılıç’tan Dijital Oyunlarda İslamofobi Uyarısı”, 22.05.2017, https://www.haberler.com/bakan-kilic-tan-dijital-oyunlarda-islamofobi9645368-haberi/

Hajli, M. N (2014). A study of the impact of social media on consumers, International Journal of Market Research, 56 (3): 387-404.

Huntington, A. (2013). Review: Trust-The Increasing Dangers for Children in a Digital World, Children's Legal Rights Journal, 34 (1): 132-134.

İçel, K. (1983) «Devletle Basın Arasındaki İlişkiler», Basın ve Basının Karşılaştığı Hukuki Sorunlar, Hürriyet Vakfı Eğitim Yayınları., No.3, İstanbul.

Ingram, J. H. (2016). A Brief History of Propaganda During Conflict: Lessons for Counter-Terrorism Strategic Communications, ICCT Research Paper, June 2016.

Jackall, R. (Eds.) 1995. Propaganda, NYU Press.

Jamali M. \& Abolhassani H. (2006). Different aspects of social network analysis. In: Proceedings of the 2006 IEEE/WIC/ACM international conference on web intelligence (WI’06) (Washington, DC, USA), IEEE Computer Society, pp 66-72. 
Jowett, G. S. \& O’Donnell, V. (2011). Propaganda \& Persuasion, Sage Publications.

Karaçor, S. (2006). Propagandanın Halkla İlişkiler ve Reklama Göre Yapı, İşleyiş Açısından Farklılıkları, İstanbul Üniversitesi İletişim Fakültesi Dergisi, Sayı 27, ss. 85-96.

Kaya, R. (1985) Kitle iletişim Sistemleri, Teori Yayınları, Ankara.

Kilduff, M. \& Tsai, W. (2003). Social Networks and Organizations, London; Thousand Oaks, Calif: Sage.

Kiry, A. (2009). Digimodernism: How New Technologies Dismantle the Postmodern and Reconfigure Our Culture, $1^{\text {st }}$ Edition, The Continuum International Publishing Group.

Kosar, R. K. (2005). Public Relations and Propaganda: Restrictions on Executive Agency Activities, CRS Report for Congress, Updated March 21, 2005, Order Code RL32750.

Kuruoğlu, H. (2006). Propaganda ve Özgürlük Aracı Olarak Radyo, Nobel: Ankara.

Lee, J. (2015). The Double-Edged Sword: The Effects of Journalists' Social Media Activities on Audience Perceptions of Journalists and Their News Products, Journal of Computer-Mediated Communication, 20 (2015): 312-329.

Little, T. A. (2017). Propaganda and credulity, Games and Economic Behavior, 102 (2017), 224-232.

Marrero, J. P. (2013). Under propaganda fire: Spain and the Great War, in War and Propaganda in the $X X^{\text {th }}$ Centruy, pp. 13-16, Rollo, F. M., Pires, P. A. \& Novais, N. M. (Eds.), Lisboa: IHC.

McQuail, D. (1994) Kitle İletişim Kuramı, Çev. A.H.Yüksel, Anadolu Üniversitesi Yayınları, Eskişehir.

Medyasyon. (2009). “Retweet Nedir? Nasil Yapilir? Neden Yapmalisiniz?”, 06.12.2009, URL: https://medyasyon.wordpress.com/2009/12/06/retweet-101/.

Mehraj, H. K., Bhat, A. N. \& Mehraj, H. R. (2014). Impacts OF Media on Society: A Sociological Perspective, International Journal of Humanities and Social Science Invention, 3 (6): 56-64.

Nadir Çetin, B. (2014). Propaganda Olgusu ve Propagandanın Amerikanlaşması, Frrat Üniversitesi Sosyal Bilimler Dergisi, 24 (2): 239-265.

Neelamalar, M. \& Chitra, P. (2009). New media and society: A Study on the impact of social networking sites on indian youth, Estudos em Comunicac, ao no6, 125-145.

Neuman, W. R. \& Guggenheim, L. (2011). The Evolution of Media Effects Theory: A Six-Stage Model of Cumulative Research, Communication Theory, 21 (2011): 169-196.

Njoroge, R. (2013). Impacts of Social Media Among The Youth On Behavior Change: A Case Study of University Students in Selected Universities in Nairobi, Kenya, A Research Project Submitted in Partial Fulfillment of The Requirement for The Master of Arts Degree in Communication Studies of The School of Journalism and Mass Communication University of Nairobi. 
Owusu-Acheaw, M. \& Larson, A. G. (2015). Use of Social Media and its Impact on Academic Performance of Tertiary Institution Students: A Study of Students of Koforidua, Journal of Education and Practice, 6 (6): 94-101.

Qualter, H. T. (1980). Propaganda Teorisi ve Propagandanın Gelişimi, Çev. Ünsal Oskay, Ankara Üniversitesi Siyasal Bilgiler Fakültesi Dergisi, 35 (1): 255-307.

Paul, R. \& Elder, L. (2004). The Thinker's Guide For Conscientious Citizens on How to Detect Media Bias \& Propaganda In National and World News, Based on Critical Thinking Concepts \& Tools, The Foundation for Critical Thinking.

Pratkanis, A. \& Aronson, E. (2001). Age of Propaganda: The Everyday Use and Abuse of Persuasion, Henry Holt and Company, LLC, USA.

Prensky, M. (2001). Digital Natives, Digital Immigrants, From On the Horizon (MCB University Press, Vol. 9 No. 5.

Pryke, S. (2012). Social Network Analysis in Construction, Chichester: Wiley-Blackwell.

Rieger, D.; Frischlich, L. \& Bente, G. (2013). Propaganda 2.0 Pyschological effects of Right-Wing and Islamic Extremist Internet Videos, In cooperation with the Terrorism/Extremism Reseacrh Unit (FTE) of the German Federal Criminal Police Office (Bundeskriminalamt).

Saunders, L. (2013). Information as Weapon: Propaganda, Politics, and the Role of the Library, ACRL 2013, pp. 309-318, April 10-13, 2013, Indianapolis, IN.

Scott, J. \& Carrington, P. J. (Eds.). (2011). The SAGE handbook of social network analysis, London; Thousand Oaks, Calif: Sage.

Sefton-Green, J., Marsh, J., Erstad, O. \& Flewitt, R. (2016). Establishing a Research Agenda for the Digital Literacy Practices of Young Children, AWhite Paper for COST Action IS1410.

Shahjahan, A. T. M. \& Chisty, K. U. (2014). Social Media Research and Its Effect on Our Society, World Academy of Science, Engineering and Technology International Journal of Information and Communication Engineering, 8 (6): 2009-2013.

Siddiqui, S. \& Singh, T. (2016). Social Media its Impact with Positive and Negative Aspects, International Journal of Computer Applications Technology and Research, 5 (2): 71-75.

Sözcü. (2018). “YSK, Cumhurbaşkanı adaylarını açıkladı”, 09.05.2018, https:// www.sozcu.com.tr/2018/gundem/ysk-cumhurbaskani-adaylariniacikladi-2398313/.

Tarhan, N. (2016). Psikolojik Savaş-Gri Propaganda, Timaş Yayınları.

Third, A., Bellerose, D., Diniz De Oliveira, J, Lala, G. \& Theakstone, G. (2017). Young and Online: Children's perspectives on life in the digital age, The State of the World's Children 2017 Companion Report.

Torres, R. M., Jordán, J. \& Horsburgh, N. (2006). Analysis and Evolution of the Global Jihadist Movement Propaganda, Terrorism and Political Violence, 18: 399-421.

Tunalı, V. (2016). Sosyal Ağ Analizine Giriş, Nobel Yayınları: Ankara.

Uçkaç Altun, S. (2010). Hitler Almanyası'nda Sanat ve Propaganda, Sanat ve Tasarım Dergisi, 1 (5): 29-39. 
Valkenburg, P. M. \& Peter, J. (2013). Five challenges for the future of media-effects research, International Journal of Communication: IJoC, 7, 197-215.

Yamamoto, J. \& Ananou, S. (2015). Humanity in the Digital Age: Cognitive, Social, Emotional, and Ethical Implications, Contemporary Educational Technology, 6 (1): 1-18.

Yegen, C. (2013). Demokratik ve Yeni Bir Kamusal Alan Olarak Sosyal Medya, ANEMON Muş Alparslan Üniversitesi Sosyal Bilimler Dergisi, 1 (2): 119-135.

Yegen, C. (2018). Siyasal İletişim, Propaganda ve Ulusal Kimlik, Kriter: İstanbul.

Yüksek Seçim Kurulu (YSK) (2018). Cumhurbaşkanı Seçimi ve 27. Dönem Milletvekili Genel Seçimi Sonuçlrı,http://www.ysk.gov.tr/doc/dosyalar/ docs/24Haziran2018/KesinSecimSonuclari/2018CB-416D.pdf, Erişim Tarihi: 12.07.2018

Walton, D. (1997). What is Propaganda, and What Exactly is Wrong With it? Public Affairs Quarterly, 11 (4): 383-413.

Williams, L. (2016). ANALYSIS Islamic State Propaganda and the Mainstream Media, The Lowy Institute for International Policy.

Woolley, C. S. \& Howard, N. P. (2017). Computational Propaganda Worldwide: Executive Summary, Working Paper No. 2017.11. The Computational Propaganda Research Project at the Oxford Internet Institute, University of Oxford, has researched the use of social media for public opinion manipulation. 
